\title{
Population genetics of the Chilean frog Batrachyla leptopus (Leptodactylidae)
}

\author{
J.R. Formas and L.M. Brieva
}

\begin{abstract}
Electrophoretic variation of proteins encoded by 14 loci was analyzed in eight (five continental and three insular) populations of the Chilean leptodactylid frog Batrachyla leptopus. The overall proportion of polymorphic loci was estimated to be $18.7 \%$ and the average number of alleles per locus, 1.2, while observed and expected heterozygosities were 1.7 and $5.1 \%$, respectively. The estimated coefficient of genetic identity was 0.940 ; the corresponding figure for genetic distance was 0.063 . F-statistics analysis showed a total inbreeding coefficient $\left(\mathrm{F}_{\mathrm{it}}\right)$ of 0.855 and high levels of genetic subdivision $\left(\mathrm{F}_{\mathrm{st}}=0.596\right)$ as well as of inbreeding within populations $\left(\mathrm{F}_{\mathrm{is}}=0.640\right)$. However, there was only a moderate level of genetic differentiation $\left(\mathrm{F}_{\mathrm{st}}=0.181\right)$ between the insular group of populations and the continental group.
\end{abstract}

\section{INTRODUCTION}

Genetic differentiation characterizes many natural disjunct animal populations, providing evidence for a reduced gene flow. Many amphibian species, including salamanders (Hedgecock, 1978; Yanev and Wake, 1981; Larson et al., 1984; Ragghianti and Wake, 1986) and frogs (Formas, 1993; Nishioka et al., 1993; Sumida and Nishioka, 1994), show substantial genetic substructuring over relatively small geographic distances.

The temperate Nothofagus forests of southern Chile and Argentina are characterized by endemism of their reduced anuran fauna (Formas, 1979). Some members of this fauna (Caudiverbera and Eupsophus) are known from the Tertiary period (Schaeffer, 1949). One species of this small group of frogs, Batrachyla leptopus Bell, is quite small (30$35-\mathrm{mm}$ snout vent length) and has a curious biology, with the eggs being deposited on the ground, near water (Busse, 1971). The main distribution of this species in Chile is continental, with some isolated populations on Chiloé Island, separated from the mainland by the Chacao channel (2.3-6 $\mathrm{km}$ wide, 50-100 $\mathrm{m}$ deep). The present distribution area of B. leptopus was intensively glaciated (Heusser and Flint, 1977; Paskoff, 1977). During the last glacial maximum $(18,000$ years BP), the insular and continental populations of $B$. leptopus were connected by a wide land bridge between Chiloé Island and the mainland (Moreno et al., 1994).

This paper describes the allozymic variability, population structure, genetic relationships, migration rate, and degree of population differentiation of eight geographic populations of B. leptopus from southern Chile.

\section{MATERIAL AND METHODS}

\section{Collection of specimens}

One hundred and eighteen tadpoles (stages 25-30)
(Gosner, 1960) were collected from eight populations in southern Chile (Figure 1). The locations and the number of specimens examined were: Valdivia Province: La Saval (39 ${ }^{\circ} 48^{\prime}$ S; $\left.73^{\circ} 14^{\prime} \mathrm{W}\right), 10$; Osorno Province: Pucatrihue $\left(40^{\circ} 26^{\prime} \mathrm{S}\right.$; 734ㄱ' $\left.\mathrm{W}\right), 15$; Puyehue (40 $41^{\prime} \mathrm{S}$; $\left.72^{\circ} 37^{\prime} \mathrm{W}\right)$, 16; La Picada (41 ${ }^{\circ} 03$ 'S; $73^{\circ} 58^{\prime} \mathrm{W}$ ), 15; Llanquihue Province: Lenca $\left(41^{\circ} 37^{\prime} \mathrm{S} ; 72^{\circ} 40^{\prime} \mathrm{W}\right), 15$; Chiloé Province: Chepu $\left(42^{\circ} 03^{\prime} \mathrm{S} ; 7^{\circ} 02^{\prime} \mathrm{W}\right), 15$; Puntra $\left(42^{\circ} 03^{\prime} \mathrm{S}\right.$; $\left.73^{\circ} 58^{\prime} \mathrm{W}\right), 16$; Dalcahue ( $42^{\circ} 23^{\prime} \mathrm{S}$; $\left.73^{\circ} 23^{\prime} \mathrm{W}\right), 16$. The tadpoles were identified according to Formas (1976). Voucher specimens were deposited in the Amphibian Collection of the Institute of Zoology, Universidad Austral de Chile (IZUA).

\section{Allozyme electrophoresis}

Voucher tadpoles were kept at $-76^{\circ} \mathrm{C}$ until processed. Eviscerated specimens were homogenized with $0.01 \mathrm{M}$ Tris-EDTA and $0.001 \mathrm{M} \beta$-mercaptoethanol, $\mathrm{pH} 7.5$. The homogenates from each specimen were centrifuged at $12,000 \mathrm{~g}$ for $15 \mathrm{~min}$ and the supernatants stored at $-76^{\circ} \mathrm{C}$, until analysis by horizontal starch gel (12\%) electrophoresis. The staining procedures followed those of Selander et al. (1971), Ayala et al. (1972) and Harris and Hopkinson (1976). The proteins assayed in the tissue extracts were glutamate oxaloacetate transaminase (GOT-1, GOT-2, Enzyme Commission [EC] 2.6.1.1), sorbitol dehydrogenase (SORDH, EC 1.1.1.14), phosphogluconate dehydrogenase (PGD, EC 1.1.1.44), purine nucleoside phosphorylase (NP, EC 2.4.2.1), hexokinase (HK, EC 2.7.1.1), phosphoglucomutase (PGM, EC 2.7.5.1), glucose phosphate isomerase (GPI, EC 5.3.1.9), lactate dehydrogenase (LDH-1, LDH-2, EC 1.1.1.27), malate dehydrogenase NAD+ (MDH-1, MDH-2, EC 1.1.1.37), and glycerol-3-phosphate dehydrogenase (GPD-1, GPD-2, EC 1.1.1.8). Electromorphs (alleles) at each locus were designated alphabetically, in order of decreasing mobility. 


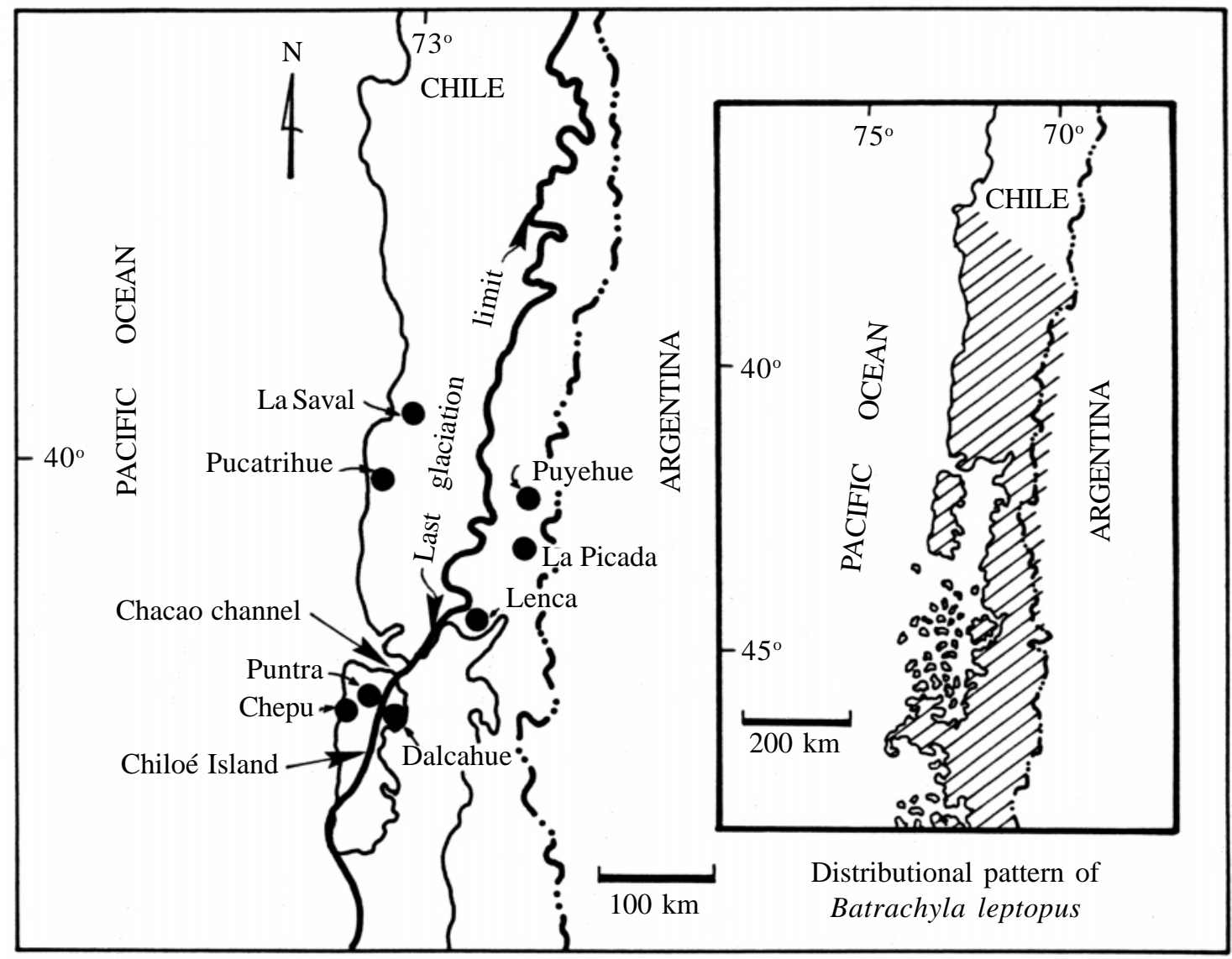

Figure 1 - Map of the locations where populations of Batrachyla leptopus were collected in southern Chile. Inset: Distribution of B. leptopus in southern Chile and Argentina.

\section{Statistical analysis}

All measures of genetic variability and population differentiation were calculated using BIOSYS-1 (Swofford and Selander, 1989). To determine whether heterozygosity levels were significantly different from those expected under panmixia, the observed and expected proportions of heterozygotes were compared by the Wilcoxon matched pairs signed rank test using the SPSS/pc +5.0 computer package (Norusis, 1992). Levene's correction for small sample sizes was applied to the data (Levene, 1949). A locus was considered polymorphic when the frequency of the major allele was $95 \%$ or less. Heterogeneity of allele frequencies among the populations was investigated for each locus with contingency $\chi^{2}$ analysis using the method of Workman and Niswander (1970).

The genetic relationships among populations were depicted by a Wagner tree (Swofford and Selander, 1989), since its algorithm does not assume a uniform rate of protein change. A population of B. taeniata from La Saval (Valdivia Province) was used as the outgroup. The intersample genetic variation, using Rogers' genetic distance (Rogers, 1972), was examined through multidimensional scaling, using NTSYS (Rohlf, 1992). The correlation be- tween genetic distance (Rogers, 1972) and geographic distance was examined by the Mantel test (Mantel, 1967), as implemented in NTSYS (Rohlf, 1992). Isolation by distance model (Wright, 1943) was analyzed with regression of $\mathrm{F}_{\mathrm{st}} /\left(1-\mathrm{F}_{\mathrm{st}}\right)$ estimates for pairs of populations on the logarithm of the geographic distance for populations (Rousset, 1997). The GENEPOP program (ISOLDE option) (Raymond and Rousset, 1997) was used to test the hypothesis of isolation by distance. F-statistics $\left(\mathrm{F}_{\mathrm{st}}, \mathrm{F}_{\mathrm{is}}\right.$, $\left.F_{i t}\right)$ were calculated according to Wright (1965), as implemented in FSTAT (Goudet, 1995), and the statistical significance per locus and among loci was tested according to Excoffier et al. (1992) and Hudson et al. (1992).

The gene flow was estimated with Slatkin's formula (1985) rare allele method, which uses the formula $\ln p$ $(1)=-0.505 \ln (\mathrm{Nm})+(-2.44)$, where $p(1)$ is the average frequency of the private alleles and $N m$ is the product of the population size and immigration rate. Because sample sizes differed among populations, the correction recommended by Slatkin (1985) was applied, in which $\mathrm{Nm}$ is divided by the ratio of the average sample size to 25 . Thus, $N m_{c}=N m(N / 25)^{-1}$, where $N=(\Sigma N i / n)$, the average sample size. $N i$ is the number of specimens in a given sample and $n$ is the number of samples studied. For our average sample 
size of $N=12.2$, the correction factor was 0.819 . The program GENEPOP 3.1 (Rohlf, 1992) was used in estimating the level of gene flow.

The method of Nei (1975) was used to estimate the maximum possible value of $m$ (migration rate) using the formula $I=m /(m+v)$, where $I$ is the Nei normalized coefficient of genetic identity and $v$ is the mutation rate. The value used for the mutation rate was $2 \times 10^{-6}$ per locus per generation. A minimum estimate of the average effective population size was derived by dividing $\mathrm{Nm}$ (derived from $\mathrm{F}_{\mathrm{st}}$ ) by $m$ (obtained from Nei's genetic identity). The insular and continental populations were grouped into two clusters, and different populational calculations were carried out separately for both groups in order to make appropriate comparisons.

\section{RESULTS AND DISCUSSION}

\section{Variation among the loci and heterozygosity}

Nine of the 14 loci were polymorphic (MDH-1, 2; GPD-2; SORDH; PGD; GPI; PGM; GOT-2; HK) and five monomorphic (LDH-1, 2; GPD-2; NP; GOT-1). The proportion of polymorphic loci ranged from 0 to $28.6 \%$, with a mean of $18.8 \%$ (Table I).

The average number of alleles per locus was 1.2. In simple regressions, percentage of polymorphic loci correlated strongly with the mean number of alleles per locus $(r=0.897)$. No significant relationships were found between sample size and percentage of polymorphic loci $(\mathrm{r}=0.319)$, and sample size and mean number of alleles per locus $(r=0.194)$.

D-statistics indicated a deficit of heterozygotes in the loci for PGD (six populations), GPI (three populations), GPD-2 (one population) and GOT (one population), and an excess in the MDH-1 locus (one population; Table I). The heterozygote deficiency was $11.1 \%$ and the heterozygote excess $1.4 \%$, suggesting that some of the populations were influenced by non-random mating (Gallardo and Köhler, 1992). The mean expected and observed heterozygosities, calculated for the populations, were 0.017 and 0.051 , respectively (Wilcoxon z value $=-3.516, \mathrm{P}<0.001)$.

Table I - Allelic frequencies, polymorphism (\%), heterozygosity (observed and expected), and mean number of alleles per locus at nine variable loci for eight populations of Batrachyla leptopus.

\begin{tabular}{|c|c|c|c|c|c|c|c|c|c|}
\hline \multirow[b]{2}{*}{ Locus } & \multirow[b]{2}{*}{ Alleles } & \multicolumn{8}{|c|}{ Populations } \\
\hline & & 1 & 2 & 3 & 4 & 5 & 6 & 7 & 8 \\
\hline \multirow[t]{3}{*}{ MDH-1 } & $\mathrm{a}$ & 0.000 & 0.000 & $0.093 *$ & 0.000 & 0.000 & 0.000 & $0.093^{*}$ & $0.000 * 0$ \\
\hline & $\mathrm{b}$ & 1.000 & 1.000 & 0.906 & 1.000 & 1.000 & 1.000 & 0.906 & 0.687 \\
\hline & $\mathrm{c}$ & 0.000 & 0.000 & 0.000 & 0.000 & 0.000 & 0.000 & 0.000 & 0.313 \\
\hline \multirow[t]{2}{*}{ MDH-2 } & $\mathrm{a}$ & 1.000 & 1.000 & 0.000 & 1.000 & 1.000 & 1.000 & 1.000 & 1.000 \\
\hline & $\mathrm{b}$ & 0.000 & 0.000 & 1.000 & 0.000 & 0.000 & 0.000 & 0.000 & 0.000 \\
\hline \multirow[t]{2}{*}{ GPD-2 } & $\mathrm{a}$ & 1.000 & 1.000 & 1.000 & $0.133 \bullet$ & 1.000 & $0.967 *$ & 1.000 & 1.000 \\
\hline & $\mathrm{b}$ & 0.000 & 0.000 & 0.000 & 0.867 & 0.000 & 0.033 & 0.000 & 0.000 \\
\hline \multirow[t]{2}{*}{ SORDH } & $\mathrm{a}$ & 0.000 & 0.000 & 0.000 & $0.200 \bullet$ & 0.000 & 0.000 & $0.000 \bullet$ & 0.000 \\
\hline & $\mathrm{b}$ & 1.000 & 1.000 & 1.000 & 0.800 & 1.000 & 1.000 & 1.000 & 1.000 \\
\hline \multirow[t]{2}{*}{ PGD } & $\mathrm{a}$ & $0.300 \bullet$ & $0.133 \bullet$ & $0.125 \bullet$ & 0.000 & $0.133 \bullet$ & 0.000 & $0.533 \bullet$ & $0.133 \bullet$ \\
\hline & $\mathrm{b}$ & 0.700 & 0.867 & 0.875 & 1.000 & 0.867 & 1.000 & 0.467 & 0.867 \\
\hline \multirow[t]{4}{*}{ GPI } & $\mathrm{a}$ & $0.050 \bullet$ & 0.000 & 0.000 & $0.000 \bullet$ & $0.033 \bullet$ & 0.000 & $0.000^{*}$ & 0.000 \\
\hline & $\mathrm{b}$ & 0.350 & 0.000 & 1.000 & 0.067 & 0.300 & 0.000 & 0.000 & 0.000 \\
\hline & $\mathrm{c}$ & 0.600 & 1.000 & 0.000 & 0.933 & 0.667 & 1.000 & 0.833 & 1.000 \\
\hline & $\mathrm{d}$ & 0.000 & 0.000 & 0.000 & 0.000 & 0.000 & 0.000 & 0.167 & 0.000 \\
\hline \multirow[t]{3}{*}{ PGM } & $\mathrm{a}$ & 0.000 & 0.000 & $0.000 *$ & $0.067 *$ & 0.000 & 0.000 & 0.000 & 0.000 \\
\hline & $\mathrm{b}$ & 1.000 & 1.000 & 0.900 & 0.933 & 1.000 & 1.000 & 1.000 & 0.929 \\
\hline & $\mathrm{c}$ & 0.000 & 0.000 & 0.100 & 0.000 & 0.000 & 0.000 & 0.000 & 0.071 \\
\hline \multirow[t]{2}{*}{ GOT-2 } & $\mathrm{a}$ & 0.000 & $0.000 \bullet$ & 0.125 & 0.000 & 0.000 & $0.000 *$ & $0.067 *$ & 0.000 \\
\hline & $\mathrm{b}$ & 1.000 & 1.000 & 0.875 & 1.000 & 1.000 & 1.000 & 0.933 & 1.000 \\
\hline \multirow[t]{2}{*}{ HK } & $\mathrm{a}$ & 0.000 & 0.133 & 0.000 & 0.000 & 0.000 & 0.000 & 0.000 & 0.000 \\
\hline & $\mathrm{b}$ & 1.000 & 0.867 & 1.000 & 1.000 & 1.000 & 1.000 & 1.000 & 1.000 \\
\hline$\%$ & & 14.3 & 14.3 & 28.6 & 28.6 & 14.3 & 0.0 & 28.6 & 21.4 \\
\hline \multicolumn{10}{|c|}{ Polymorphism } \\
\hline \multicolumn{2}{|c|}{ H observed } & 0.007 & 0.000 & 0.013 & 0.010 & 0.005 & 0.005 & 0.056 & 0.045 \\
\hline \multicolumn{2}{|c|}{ H expected } & 0.070 & 0.034 & 0.058 & 0.059 & 0.051 & 0.005 & 0.079 & 0.059 \\
\hline \multicolumn{2}{|c|}{$\begin{array}{l}\text { Mean number of } \\
\text { alleles per locus }\end{array}$} & 1.2 & 1.1 & 1.3 & 1.3 & 1.2 & 1.1 & 1.3 & 1.2 \\
\hline
\end{tabular}

The following loci were fixed for the same allele in all populations: LDH-1, LDH-2, GPD-1, NP, and GOT-1. Population: 1 (La Saval), 2 (Pucatrihue), 3 (Puyehue), 4 (La Picada), 5 (Lenca), 6 (Chepu), 7 (Puntra), and 8 (Dalcahue). * Genotypic frequencies for these loci and populations deviate significantly $(\mathrm{P}<0.01)$ from Hardy-Weinberg expectations. $\bullet$ Loci and populations with a significant $(\mathrm{P}<0.01)$ heterozygote deficit. ${ }^{\circ}$ Locus and population with a significant $(\mathrm{P}<0.01)$ heterozygote excess. 
Genetic population structure, gene flow, and effective population size

The heterogeneity of allele frequencies among the populations, investigated for each locus with contingency $\chi^{2}$ analysis (Workman and Niswander, 1970), revealed significant heterogeneity in allele frequencies among populations $\left(\chi^{2}=870\right.$, d.f. $\left.=91, \mathrm{P}<0.001\right)$. The high values of heterogeneity among populations indicate similarly high levels of inbreeding of further population subdivision as suggested by the positive $F_{\text {is }}(0.640)$ values (Chesser, 1983) .

The standardized variance of allele frequencies indicated a high level of interpopulational genetic differentiation $\left(\mathrm{F}_{\mathrm{st}}=0.596, \mathrm{P}<0.005\right)$. On average, $60 \%$ of the total variance of allele frequencies was attributable to genetic differentiation among the populations whereas $40 \%$ was found within populations.

The high positive value for $\mathrm{F}_{\mathrm{it}}(0.855, \mathrm{P}<0.005)$ indicated a greater number of homozygous individuals relative to that expected, when the data for all populations were pooled. The high positive $F_{\text {is }}$ value $(0.640, \mathrm{P}<0.005)$, due to excess homozygotes within populations, indicated high levels of inbreeding in these populations of B. leptopus.

The estimate of gene flow, using the rare alleles method (Table I; Slatkin, 1985), was one migrant per 1.6 generations, which is not strong enough to counteract the effects of drift. The estimate of the minimum effective population size was 5600 individuals (the $\mathrm{Nm}$ and $m$ values were 0.17 and $3 \times 10^{-5}$, respectively). Since the $\mathrm{Nm}$ was very low, we concluded that the populations of B. leptopus were highly differentiated (Hartl and Clark, 1989).

\section{Genetic and geographical correlation}

The average genetic identity was 0.940 (Table II). The hierarchical analysis, based on Rogers' genetic distance (Rogers, 1972), produced clusters of populations that did not conform to their north-south distributional patterns (see Figures 1 and 2). The populations of La Picada and Chepu, $157 \mathrm{~km}$ apart, were grouped in the same cluster

Table II - Nei's genetic identity (1978) (above the diagonal) and Rogers' genetic distance (Rogers, 1972) (below the diagonal) for populations of Batrachyla leptopus.

\begin{tabular}{|lcccccccc|}
\hline Populations & 1 & 2 & 3 & 4 & 5 & 6 & 7 & 8 \\
\hline 1 Lenca & - & 0.934 & 0.998 & 0.981 & 0.985 & 0.991 & 0.991 & 0.887 \\
2 La Picada & 0.108 & - & 0.925 & 0.915 & 0.931 & 0.946 & 0.938 & 0.795 \\
3 La Saval & 0.016 & 0.125 & - & 0.987 & 0.979 & 0.983 & 0.986 & 0.889 \\
4 Puntra & 0.059 & 0.141 & 0.051 & - & 0.979 & 0.976 & 0.984 & 0.844 \\
5 Dalcahue & 0.050 & 0.118 & 0.066 & 0.070 & - & 0.991 & 0.991 & 0.842 \\
6 Chepu & 0.035 & 0.083 & 0.051 & 0.064 & 0.039 & - & 0.997 & 0.849 \\
7 Pucatrihue & 0.032 & 0.105 & 0.048 & 0.061 & 0.037 & 0.021 & - & 0.847 \\
8 Puyehue & 0.144 & 0.245 & 0.151 & 0.178 & 0.174 & 0.177 & 0.176 & - \\
\hline
\end{tabular}

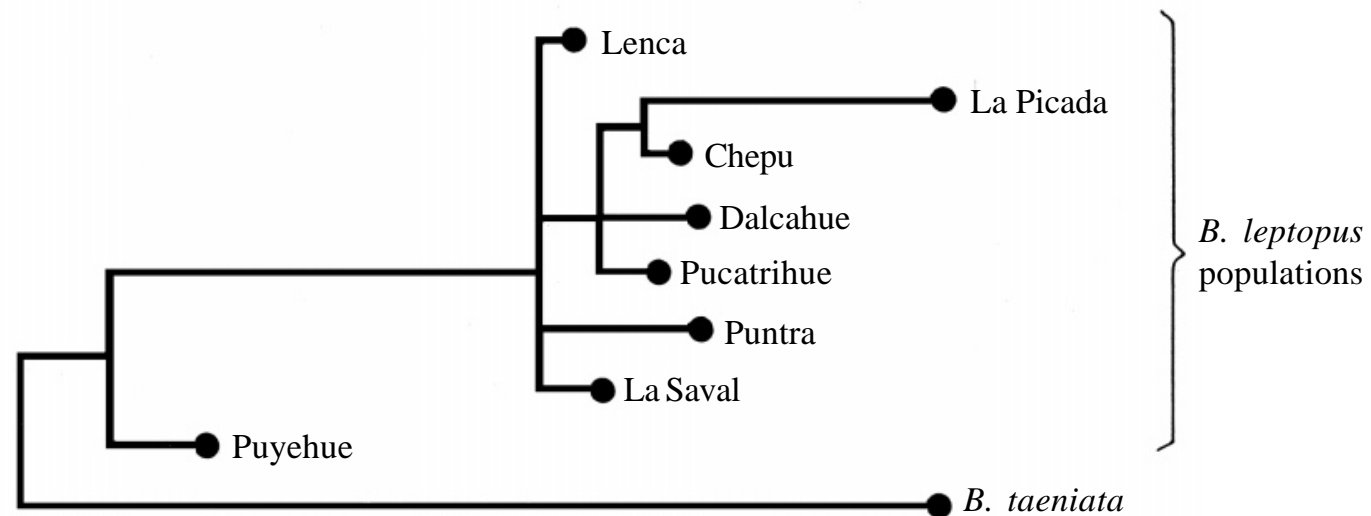

(La Saval population)

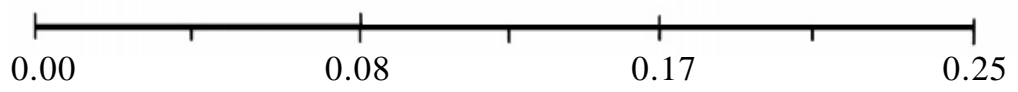

Distance from root

Figure 2 - Wagner tree showing the allozymic relationships among Batrachyla leptopus populations. The tree was rooted using the outgroup method. Cophenetic correlation $=0.999$. 
since they shared an equal degree of genetic similarity (Table II). In contrast, the Puyehue and La Picada populations, $50 \mathrm{~km}$ apart, were allocated separately. The Mantel test for a correlation between matrices of Rogers' (1972) genetic distance and geographic distance was not significant $(r=-0.082, P=0.330)$, indicating that genetic similarity does not correspond to geographic proximity.

The isolation-by-distance test indicated a lack of significant correlation $(r=0.651)$ between $F_{s t} /\left(1-F_{s t}\right)$ and the logarithm of geographical distance (Rousset, 1997). This shows that the genetic differentiation is not related to the geographical distance. On the other hand, it suggests that this species may have only recently invaded this area since it is not in equilibrium (Slatkin, 1993). The lack of association between genetic differentiation and geographical distances suggests differentiation by a founder effect, mutation, and drift (Mayr, 1968; Chesser, 1983).

The southwestern part of South America was affected by three to four pleistocenic glaciations which reached the eastern slopes of the coastal range (Figure 1) (Paskoff, 1977). The last of these glaciations occurred between 20,500 and 14,000 years BP (Mercer, 1972). Consequently, most animal and plant species were displaced to the western slopes, where they remained in refugial areas (Formas, 1979; Ashworth and Hoganson, 1993; Villagrán et al., 1996). After retreat of the glaciers, B. leptopus populations may have recolonized their primitive areas of distribution. Based on this scenario, the lack of correlation between genetic and geographical distances is interpreted as the result of a relatively recent recolonization from the west. The allozymic data are consistent with the notion that a founder effect and genetic drift were associated with these post-glacial events.

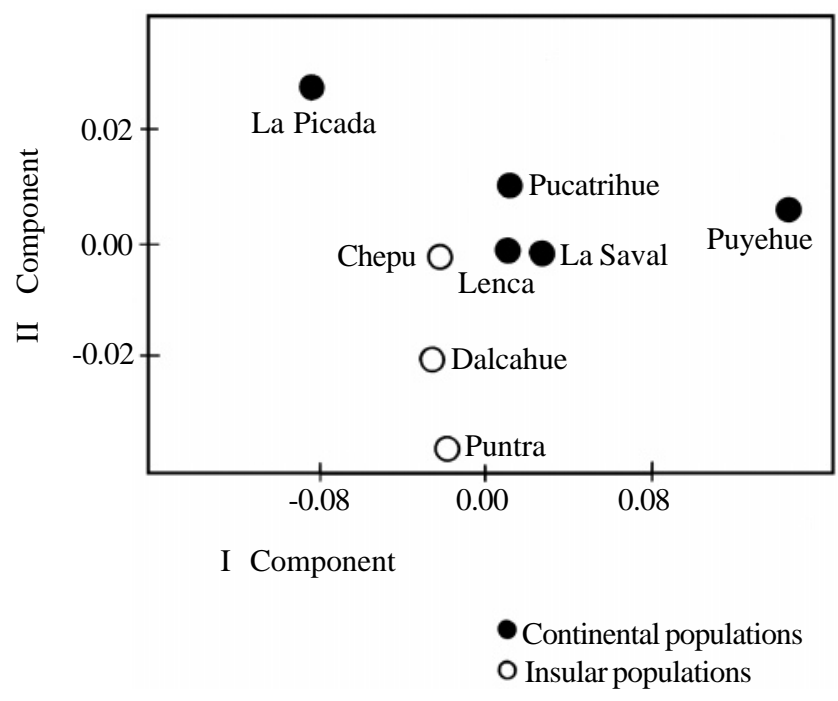

Figure 3 - Bi-dimensional ordination of the eight populations of Batrachyla leptopus using the multidimensional scaling method.
Insular and continental populations

The continental group of populations was significantly more polymorphic $(28.6 \%)$ than the insular one $(21.4 \%)$, and the mean number of alleles per locus was also higher in the continental (1.8) than in the insular group (1.5). The mean heterozygosity was lower in the mainland populations ( $0.7 \%$ direct-count, $11.8 \%$ expected) than in the Chiloé Island populations (3.5\% direct-count, 5.8\% expected). The $\mathrm{F}_{\mathrm{st}}$ value (0.181) and the Rogers' genetic distance (0.017) indicated a low degree of differentiation between these two groups of populations.

The hierarchical analysis (Wagner tree) built on Rogers' genetic distance produced a topology not totally consistent with the populations' geography. Using Rogers' genetic distances, interpopulational genetic variation was further examined. Non-hierarchical, multidimensional scaling allowed two slightly different sets of populations to be recognized: an insular group (Puntra, Chepu, Dalcahue) and a continental one (La Saval, Pucatrihue, Puyehue, La Picada and Lenca) (Figure 3).

The calculated gene flow, using the rare alleles method (Table I; Slatkin, 1985), between the insular and continental populations was one immigrant per three generations, and does not agree with the known situation. Since these animals have very little tolerance of salt water, oceans are effective barriers to dispersal (Porter, 1972). The estimated gene flow between the Chiloé Island and mainland populations was interpreted as resulting from genetic interchanges that took place when both areas were connected during the last glacial maximum $(18,000$ years BP) by a wide land bridge (Climap, 1981; Moreno et al., 1994). The low values for Rogers' genetic distance (0.017) and genetic differentiation $\left(\mathrm{F}_{\mathrm{st}}=0.181\right)$ between the insular and continental populations of B. leptopus are consistent with this scenario.

The level of gene flow and the genetic distances between insular and continental populations of B. leptopus suggest that the Chacao channel has acted as a recent barrier to gene flow between these groups of populations.

\section{ACKNOWLEDGMENTS}

The authors thank Dr. Milton Gallardo, Dr. Ricardo Galleguillos and three anonymous reviewers for critical comments. This research was supported by the Fondo Nacional de Ciencia y Tecnología (FONDECYT, grant 1940869).

\section{RESUMO}

A variação eletroforética de proteínas codificadas por 14 loci foi analisada em oito populações ( 5 continentais e 3 insulares) da rã leptodactilídea chilena Batrachyla leptopus. A proporção geral de loci polimórficos foi estimada como sendo de $18,7 \%$ e o número médio de alelos por loco, 1,2, enquanto que as heterozigosidades observada e esperada foram 1,7 e $5,1 \%$, respectivamente. $\mathrm{O}$ coeficiente esperado de identidade genética foi 0,940; o número correspondente para a distância genética foi 
0,063. A análise estatística $F$ mostrou um coeficiente de endogamia total $\left(\mathrm{F}_{\mathrm{i} t}\right)$ de 0,855 e altos níveis de subdivisão genética $\left(\mathrm{F}_{\mathrm{st}}=\right.$ $0,596)$, assim como de endogamia dentro das populações $\left(\mathrm{F}_{\mathrm{is}}=\right.$ $0,640)$. Contudo, houve apenas um nível moderado de diferenciação genética $\left(\mathrm{F}_{\mathrm{st}}=0,181\right)$ entre o grupo insular de populações e o grupo continental.

\section{REFERENCES}

Ashworth, A.C. and Hoganson, J.W. (1993). The magnitude and rapidity of the climate change marking the end of the Pleistocene in the midlatitudes of South America. Palaeogeogr. Palaeoclimatol. Palaeoecol. 101: 263-270.

Ayala, F.J., Powell, J.R., Tracey, M.L., Mourao, C.A. and Pérez-Salas, S. (1972). Enzymatic variability in the Drosophila willistoni group. Genetic variation in natural populations of Drosophila willistoni. Genetics 70: 113-139.

Busse, K. (1971). Desarrollo de Batrachyla leptopus Bell con observaciones sobre su ecología y comportamiento (Amphibia; Leptodactylidae). Invest. Zool. Chil. 15: 5-63.

Chesser, R.K. (1983). Genetic variability within and among populations of the black-tailed prairie dog. Evolution 37: 320-331.

Climap Project Members (1981). Seasonal reconstructions of the earth's surface at the last glacial maximum. Geol. Soc. Am. (Map Chart Series MC) $36: 1-18$

Excoffier, Y., Smouse, P.E. and Quattro, J.M. (1992). Analysis of molecular variance inferred from metric distances among DNA haplotypes. Application to human mitochondrial DNA restriction data. Genetics 131: $479-491$

Formas, J.R. (1976). Descriptions of Batrachyla (Amphibia, Anura, Leptodactylidae) tadpoles. J. Herpetol. 10: 221-225.

Formas, J.R. (1979). La herpetofauna de los bosques temperados de Sudamérica. In: The South American Herpetofauna (Duellman, W.E., ed.). Monograph 7, Museum of Natural History, University of Kansas, Lawrence, Kansas, pp. 341-379.

Formas, J.R. (1993). Allozymic and morphological differentiation between two South American frogs, genus Eupsophus (E. vertebralis and E. emiliopugini). Comp. Biochem. Physiol. 106B: 77-81.

Gallardo, M.H. and Köhler, N. (1992). Genetic divergence in Ctenomys (Rodentia, Ctenomyidae) from the Andes of Chile. J. Mammal. 73: 99-105.

Gosner, K.L. (1960). A simplified table for staging anuran embryos and larvae with notes on identification. Herpetologica 16: 183-190.

Goudet, J. (1995). FSTAT (version: 1.2): A computer program to calculate F-statistics. J. Heredity 86: 485-486.

Harris, H. and Hopkinson, D.A. (1976). Handbook of Enzyme Electrophoresis in Human Genetics. North-Holland Publishing Company, North-Holland, Amsterdam.

Hartl, D.L. and Clark, G.C. (1989). Principles of Population Genetics. Sinauer Associates, Sunderland, Massachusetts.

Hedgecock, D. (1978). Population subdivision and genetic divergence in the red-bellied newt, Taricha rivularis. Evolution 32: 271-286.

Heusser, C.J. and Flint, R.F. (1977). Quaternary glaciations and environments of northern Isla Chiloé, Chile. Geology 5: 305-308.

Hudson, R.R., Boos, D.D. and Kaplan, N.L. (1992). A statistical test for detecting geographic subdivision. Mol. Biol. Evol. 9: 138-151.

Larson, A., Wake, D.B. and Yanev, K.P. (1984). Measuring gene flow among populations having high levels of genetic fragmentation. Genetics 106: 293-308

Levene, H. (1949). On a matching problem arising in genetics. Ann. Math Stat. 20: $91-94$

Mantel, N. (1967). The detection of disease clustering and a generalized regression approach. Cancer Res. 27: 209-220.

Mayr, E. (1968). Especies Animales y Evolución. Ediciones de la Univer- sidad de Chile, Santiago de Chile

Mercer, J.H. (1972). Chilean glacial chronology 20,000 to 11,000 carbon-14 years ago: some global comparisons. Science 176: 1118-1120.

Moreno, P.Y., Villagrán, C., Marquet, P.A. and Marshall, L.G. (1994). Quaternary paleobiogeography of northern and central Chile. Rev. Chil. Hist. Nat. 67: 487-502.

Nei, M. (1975). Molecular Population Genetics and Evolution. American Elsevier, New York.

Nei, M. (1978). Estimation of average heterozygosity and genetic distance from a small number of individuals. Genetics 89: 583-590.

Nishioka, M., Kodama, Y., Sumida, M. and Ryuzaki, M. (1993). Systematic evolution of 40 populations of Rana rugosa distributed in Japan elucidated by electrophoresis. Sci. Rep. Lab. Amphib. Biol. Hiroshima Univ. 12: 83-131.

Norusis, M.J. (1992). SPSS/PC + Base System Users' Guide, Version 5.0. SPSS Inc., Chicago.

Paskoff, R.P. (1977). Quaternary of Chile: the state of research. Quatern. Res. 8: 2-31

Porter, K.R. (1972). Herpetology. W.B. Saunders, Philadelphia.

Ragghianti, M. and Wake, D.B. (1986). Genic variation and its evolutionary implications in the Italian newt, Triturus italicus. Herpetologica 42: 206-214.

Raymond, M. and Rousset, F. (1997). GENEPOP (version 3.1). Updated version of Genepop (version 1.2): population genetics software for exact tests and ecumenicism. J. Heredity 86: 248-249.

Rogers, J.S. (1972). Measures of genetic similarity and genetic distance. Stud. Genet. VII (Univ. Texas Publ.) 7213: 145-153.

Rohlf, F.J. (1992). NTSYS-pc. Numerical Taxonomy and Multivariate Analysis System, Version 1.7. Exeter Software, New York.

Rousset, F. (1997). Genetic differentiation and estimation of gene flow from F-statistics under isolation by distance. Genetics 145: 1219-1228.

Schaeffer, B. (1949). Anurans from the early Tertiary of Patagonia. Bull. Am. Mus. Nat. Hist. 93: 47-68.

Selander, R.K., Smith, M.H., Yang, S.Y., Johnson, W.E. and Gentry J.B. (1971). Biochemical polymorphism and systematics of Peromyscus. I. Variation in the old field mouse Peromyscus polionotus. Stud. Genet. VI (Univ. Texas Publ.) 7103: 49-90.

Slatkin, M. (1985). Rare alleles as indicators of gene flow. Evolution 39: 53-65.

Slatkin, M. (1993). Isolation by distance in equilibrium and non-equilibrium populations. Evolution 47: 264-279.

Sumida, M. and Nishioka, M. (1994). Genetic differentiation of the Japanese brown frog, Rana japonica, elucidated by electrophoretic analyses of enzymes and blood proteins. Sci. Rep. Lab. Amphib. Biol. Hiroshima Univ. 13: 137-171.

Swofford, D.L. and Selander, R.B. (1989). BIOSYS-1. A Computer Program for the Analysis of Allelic Variation in Population Genetics and Biochemical Systematics. Illinois Natural History Survey, Champaign.

Villagrán, C., Moreno, P. and Villa, R. (1996). Antecedentes palinológicos acerca de la historia cuaternaria de los bosques chilenos. In: Ecología de los Bosques Nativos de Chile (Armesto, J.J., Villagrán, C. and Arroyo, M.K., eds.). Editorial Universitaria, Universidad de Chile, Santiago, pp. 51-69.

Workman, P.L. and Niswander, J.D. (1970). Population studies on Southwestern Indian tribes, II. Local genetic differentiation in the Papago. Am. J. Hum. Genet. 22: 24-49.

Wright, S. (1943). Isolation by distance. Genetics 28: 139-156

Wright, S. (1965). The interpretation of population structure by F-statistics with special reference to systems of mating. Evolution 1:395-420.

Yanev, K.P. and Wake, D.B. (1981). Genic differentiation in a relict desert salamander, Batrachoseps campi. Herpetologica 37: 16-28.

(Received November 9, 1998) 